\title{
ПРЕДВАРИТЕЛЬНЫЕ РЕЗУЛЬТАТЫ ИССЛЕДОВАНИЙ ПАМЯТНИКОВ ЭПОХИ ПАЛЕОМЕТАЛЛА ЖЕЗКАЗГАН-УЛЫТАУСКОГО РЕГИОНА в 2020 гОДУ
}

\author{
(c) 2020 ж. Дархан Айтжанұлы Байтілеу르, \\ Арман Жилкайдарович Бермагамбетов², \\ Айдар Шарханович Искаков ${ }^{3}$, Жанаргуль Сериковна Калиева ${ }^{1}$
}
${ }^{1}$ кандидат исторических наук, ведущий научный сотрудник, Институт археологии им. А. Х. Маргулана, г. Алматы, Казахстан. E-mail: baitileu@gmail.com ${ }^{2}$ главный специалист, Историко-производственный музей имени академика К.И. Сатпаева, г. Жезказган, Казахстан. E-mail: armankerey@mail.ru ${ }^{3}$ научный сотрудник, Музей истории горного и плавильного дела имени Макена Торегелдина. г. Жезказган, Казахстан. E-mail: iskakov.aydar@list.ru ${ }^{1}$ магистр археологии и этнологии, научный сотрудник, Институт археологии им. А. Х. Маргулана, г. Алматы, Казахстан. E-mail: zhkalieva@mail.ru

Аннотация. В статье представлены предварительные результаты исследования геоархеологических производственных объектов и археологических памятников различных категорий эпохи бронзы в Улытауском районе Карагандинской области, которые были проведены в 2020 году в рамках исполнения задач по грантовой теме «Горное дело и металлургия Центрального Казахстана в эпоху палеометалла». В ходе проведенных исследований была дополнена база данных археологических памятников эпохи палеометалла и связанных с ними геоархеологических производственных объектов Жезказган-Улытауского региона. Проведенные работы позволили провести корреляциюраспространенияархеологическихпамятниковигеолого-минералогической приуроченности рудников эпохи бронзы в Улытау-Жезказганском регионе.

Ключевые слова: археология, Улытау-Жезказганский регион, эпоха бронзы, горное дело, археометаллургия

\section{ЖЕЗҚАЗҒАН-ҰЛЫТАУ АЙМАҒЫНЫН ПАЛЕОМЕТАЛ ДӘУІРІ ЕСКЕРТКІШТЕРІН 2020 ЖЫЛҒЫ ЗЕРТТЕУЛЕРДІН АЛҒАШҚЫ НӘТИЖЕЛЕРІ}

\section{Дархан Айтжанұлы Байтілеу로 Арман Жылқайдарұлы Бермағамбетов², Айдар Шарханұлы Искаков ${ }^{3}$, Жанаргүл Серікқызы Қалиева ${ }^{1}$}

\footnotetext{
${ }^{1}$ тарих ғылымдарының кандидаты, жетекші ғылыми қызметкері, Ә. Х. Марғұлан атындағы Археология институты, Алматы қ., Қазақстан. E-mail: baitileu@gmail.com

${ }^{2}$ бас маманы, академик Қ. И. Сәтбаев атындағы Тарихи-өндірістік мұражайы Жезқазған қ., Қазақстан. E-mail: armankerey@mail.ru
} 
${ }^{3}$ ғылыми қызметкері, Мәкен Төрегелдин атындағы Тау-кен және балқыту iсi тарихы музейі Жезқазған қ., Қазақстан. E-mail: iskakov.aydar@list.ru ${ }^{1}$ археология және этнология магистрі, ғылыми қызметкер, Ә. Х. Марғұлан атындағы Археология институты, Алматы қ, Қазақстан. E-mail: zhkalieva@mail.ru

Аннотация. Мақалада 2020 жылы «Орталық Қазақстан тау-кен металлургиясы палеометал дәуірінде» гранттық жобасы шеңберінде жүзеге асырылып, орындалған Қарағанды облысының Ұлытау ауданындағы қола дәуірінің әр түрлі санаттағы геоархеологиялық өндіріс орындары мен археологиялық орындарын зерттеудің алдын-ала нәтижелері берілген. Зерттеу барысында Жезқазған-Ұлытау аймағының палеометалды және онымен байланысты геоархеологиялық өндіріс орындарының археологиялық ескерткіштері туралы мәліметтер базасы толықтырылды. Жүргізілген жұмыс Ұлытау-Жезқазған аймағындағы қола дәуіріндегі археологиялық алаңдардың және шахталардың геологиялық-минералогиялық қамтылуын өзара байланыстыруға мүмкіндік берді.

Түйін сөздер: археология, қола дәуірі, тау-кен ісі, археометаллургия, ҰлытауЖезқазған аймағы

\section{PRELIMINARY RESULTS of the STUDY of MONUMENTS of the PALEOMETAL AGE of JEZKAZGAN-ULYTAU REGION in 2020}

\section{Darkhan A. Baitileu ${ }^{1}$, Arman Zh. Bermagambetov², Aydar Sh. Iskakov ${ }^{3}$, Zhanargul S. Kalieva ${ }^{1}$}

${ }^{1}$ Candidate of Historical Sciences, Leading Researcher, A.Kh. Margulan Archeology Institute, Almaty, Kazakhstan. E-mail: baitileu@gmail.com

${ }^{2}$ Chief Specialist, Historical and Production Museum named after academician

K.I. Satbayev, Jezkazgan, Kazakhstan. E-mail: armankerey@mail.ru

${ }^{3}$ Researcher, Maken Toregeldin Museum of the History of Mining and Smelting. Jezkazgan, Kazakhstan. E-mail: iskakov.aydar@list.ru

${ }^{1}$ Master of archaeology and ethnology, Research Fellow, A.Kh. Margulan Archeology Institute, Almaty, Kazakhstan. E-mail: zhkalieva@mail.ru

Abstract. This article presents the preliminary results of the study of geoarchaeological production facilities and archaeological sites of various categories of the Bronze Age in the Ulytau district of the Karagandy region, which were carried out in 2020 as part of the tasks on the grant topic "Mining and metallurgy of Central Kazakhstan in the age of paleometal". In the course of the research, the database of archaeological monuments of the age of the paleometal and associated geoarchaeological production facilities of the Jezkazgan-Ulytau region was supplemented. The work carried out made it possible to correlate the distribution of archaeological sites and the geological and mineralogical confinement of mines of the Bronze Age in the Ulytau-Jezkazgan region.

archaeometallurgy

Keywords: archaeology, Ulytau-Jezkazgan region, Bronze Age, mining,

\section{Введение}

В полевом сезоне 2020 года Жезказган-Улытауский отряд Института археологии им. А. Х. Маргулана проводил ряд археологических изысканий в Улытауском районе Карагандинской области в рамках исполнения задач по теме «Горное дело и металлургия Центрального Казахстана в эпоху палеометалла». Исходя из основной цели научного изыскания, а именно - решения проблем установления закономерностей локализации медных месторожде- 
ний различных типов и освоения меднорудных ресурсов для горнометаллургического производства в Жезказган-Улытауском регионе в эпоху палеометалла, авторами проекта было решено провести изыскания в двух основных направлениях, которые тесно взаимосвязаны между собой. Первое направление ориентировано на комплексное исследование геоархеологических производственных объектов эпохи палеометалла на площади медных месторождений в пределах Жезказган-Улытауского горно-металлургического центра (ГМЦ), что в дальнейшем позволит выявить особенности металлогенических комплексов, являвшихся потенциальными объектами освоения меднорудных запасов в период становления металлургии меди, а также сделать прогнозную оценку минеральносырьевого потенциала региона. Второе направление ориентировано на определение и изучение особенностей технологий металлургической переработки руд, а также выявление новых археологических памятников в Жезказган-Улытауском регионе, связанных с металлургическим производством, для последующей реконструкции механизмов функционирования горно-металлургических центров региона в эпоху бронзы.

\section{Описание материала}

В полевом сезоне 2020 г. исследования были проведены в южном, юго-западном и западном направлении от Улытауского горного массива, а также в районе Большого Жезказгана. Были проведены рекогносцировочные работы в районе спутников г. Сатпаев, гор Кишитау, в УлытауКарсакпайском регионе, среднем течении реки Жезды и в районе бассей- на реки Кенгир, низовьях и в среднем течении реки Кара Кенгир, а также многочисленных притоков основных водных бассейнов региона.

Выбор конкретных мест для рекогносцировочных исследований предопределен ранними изысканиями, проведенными учеными в XX в. [Валукинский, 1949a, б, в; Маргулан, 1948, 1960; Маргулан, Агеева, 1948; Маргулан и др., 1966; Сатпаев, 1941, 1956].

В ходе поиска археологических объектов в окрестностях гг. Жезказган и Сатпаев, большая часть которых была выявлена Н. В. Валукинским [1949a, б], а также обследована в ходе работ Центрально-Казахстанской археологической экспедиции [Маргулан, Агеева, 1948; Маргулан, 2001], было определено, что большая часть геоархеологических производственных объектов и археологических памятников различных категорий эпохи бронзы, к сожалению, в настоящий момент разрушены, либо занесены современными постройками и террикониками. Единичные обломки каменных орудий горного дела были обнаружены лишь на южной оконечности пос. Весовая, спутника г. Сатпаев. Геоархеологический производственный объект либо археологический памятник эпохи бронзы, локализованный в пос. Весовая, к сожалению, в аварийном состоянии и занесен отходами современной производственной деятельности и в настоящий момент не подлежит идентификации как памятник археологии (рис. 1). К сожалению, подобное аварийное состояние памятников фиксируется на местонахождениях Милыкудук, Соркудук, Покровский, Крестовский, Никольский и др. 


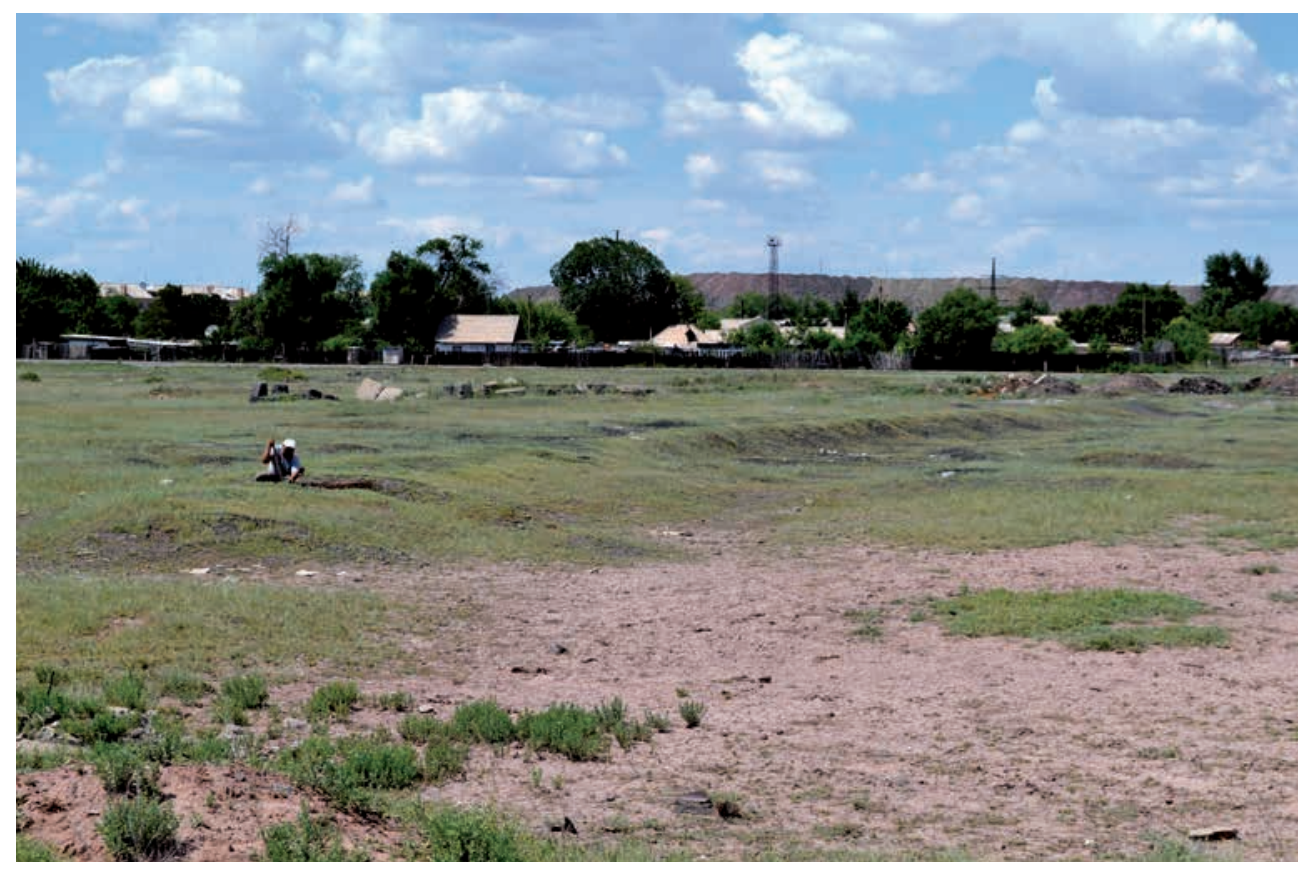

Рис. 1. Место локализации геоархеологического производственного объекта эпохи бронзы близ пос. Весовая. Фото авторов

Fig. 1. Place of localization of the geoarchaeological production facility of the Bronze Age near the village Wesovaya. Authors's photo

С целью изучения древних выработок, обозначенных К. И. Сатпаевым [1956], был обследован ряд местонахождений западной половины Жезказган-Улытауского региона. Среди перспективных для дальнейшего изучения можно назвать пределы Кишитауского поднятия, а именно месторождение Алтын-Казган II (Карашокы), расположенного в 50 км к северо-западу от пос. Карсакпай. На месторождении Алтын-Казган II К. И. Сатпаев обнаружил древний ка-

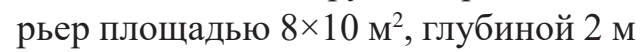
[1956, с. 43]. Описанный К. И. Сатпаевым древний рудник в настоящий момент разрушен вследствие работ действующего карьера Алтын-Казган (рис. 2). Несмотря на активное современное освоение полезных ископаемых в районе Кишитауского поднятия, данный район достаточно пер- спективен для дальнейшего изучения геоархеологических производственных объектов и археологических памятников эпохи бронзы.

В ходе рекогносцировочных работ вдоль среднего течения реки Улкен Жезды, в урочище Балкан, в 10 км к северо-западу от известного памятника древней металлургии поселения эпохи бронзы Талдысай, было обнаружено разновременное поселение.

В восточной части второй надпойменной террасы, размеры которой составляют $200 \times 50$ м, обнаружены преимущественно мелкие фрагменты неорнаментированной керамики эпохи поздней бронзы. В средней части террасы прослеживается значительное скопление окисленной руды (рис. 3), которая условно разделяет террасу на два участка локализации находок. В западной части террасы, 


\section{ҚАЗАҚСТАН АРХЕОЛОГИЯСЫ № 3 (9) 2020}

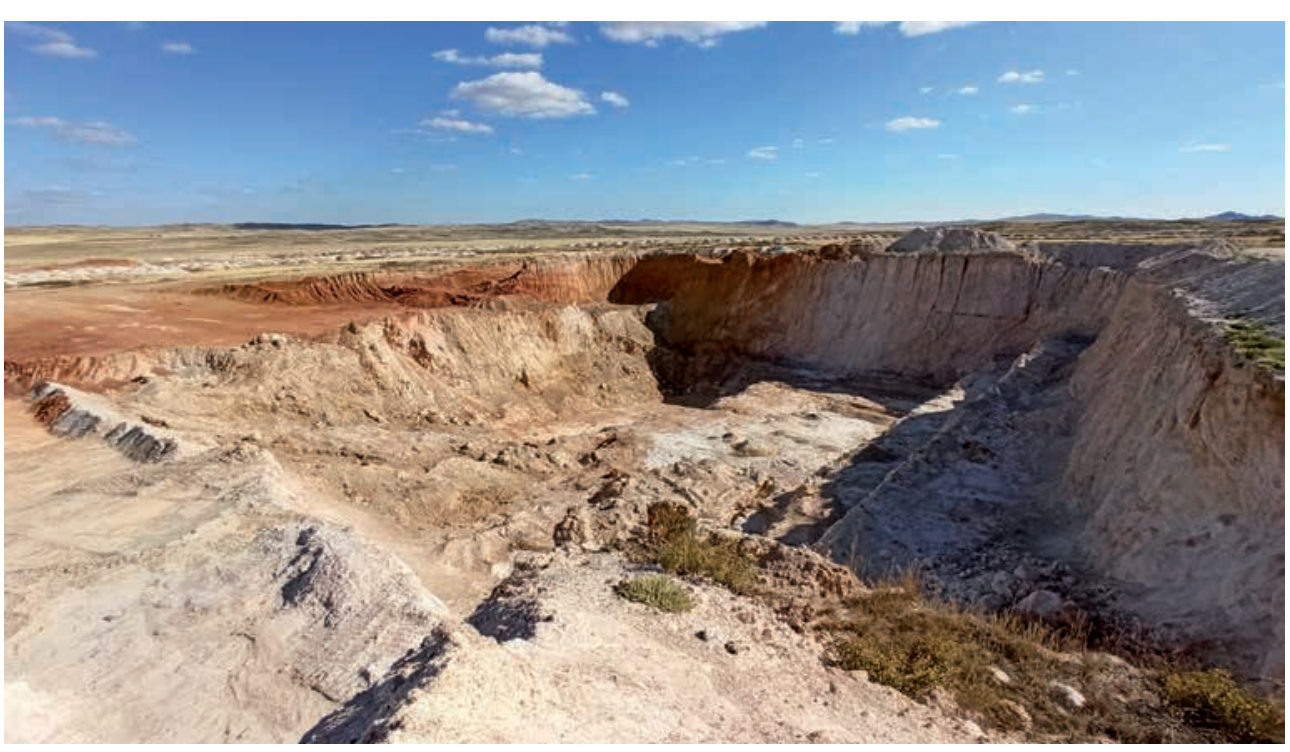

Рис. 2. Вид на современный карьер Алтын-Казган. Фото авторов

Fig. 2. View of the modern quarry Altyn-Kazgan. Authors's photo

которая граничит с возвышенностью, а также в пойме реки обнаружены

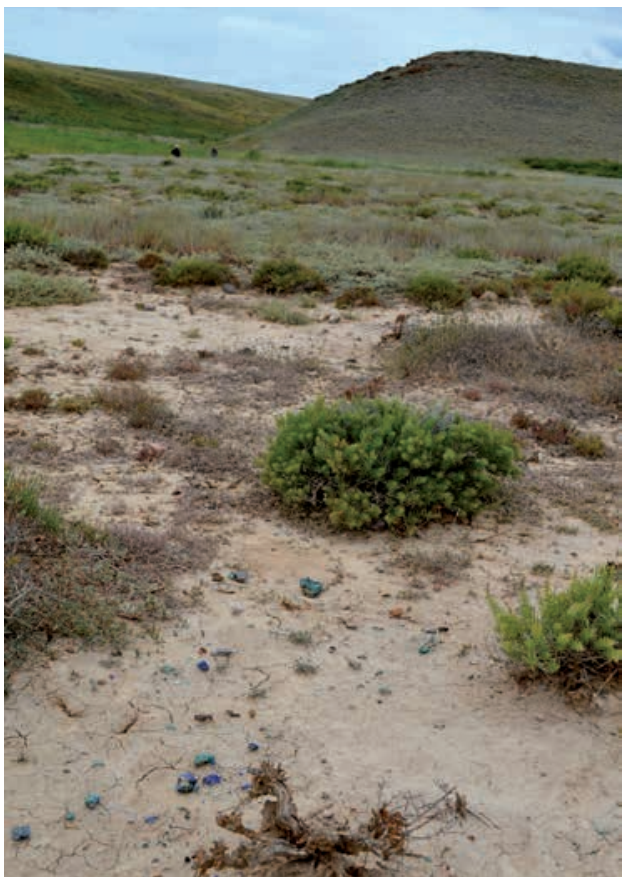

Рис. 3. Поселение Балкан. Скопление окисленной руды. Фото авторов

Fig. 3. Settlement of the Balkan. Accumulation of oxidized ore. Authors's photo многочисленные кости животных, фрагменты керамики, шлаки, окисленная руда. В данном месте был заложен археологический раскоп для культурной и хронологической идентификации памятника.

Стратиграфия раскопа на поселении Балкан показала наличие двух культурных горизонтов - ранний (эпохи бронзы) и поздний (ранний железный век). Культурный слой эпохи бронзы представлен серым суглинком с отдельными зольными включениями. На данном горизонте обнаружены остатки окисленной руды, многочисленные фрагменты керамики, шлаки и иные находки. За пределами раскопа, заложенного на краю террасы, был зафиксирован слиток металла (бронза?), а также детское захоронение (скелет ребенка на левом боку в скорченном положении) (рис. 4). Обнаруженный остеологический материал достаточно разнообразен и требует дальнейшего специального изучения. Примечательно, что 


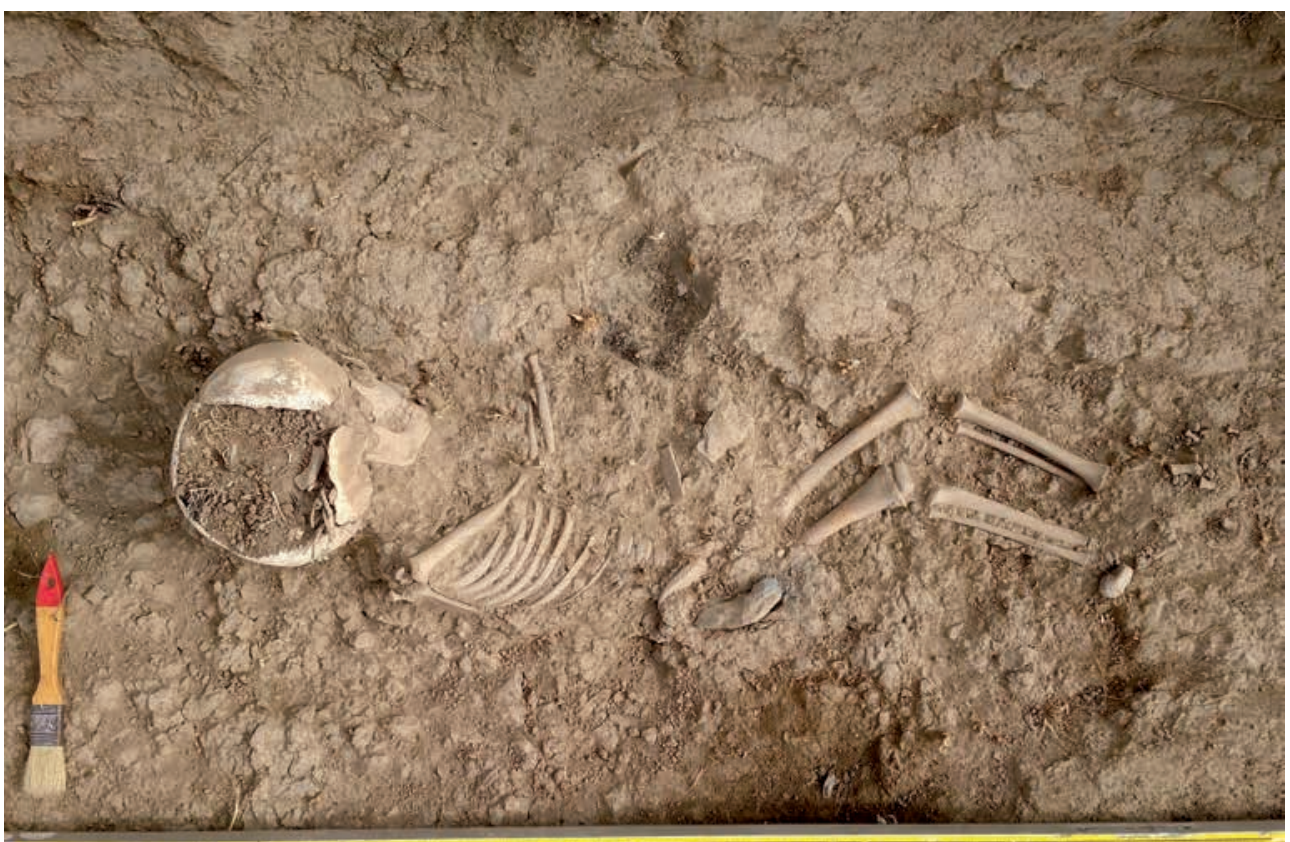

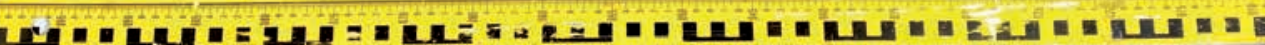

Рис. 4. Поселение Балкан. Детское захоронение. Фото авторов

Fig. 4. Settlement of the Balkans. Children's burial. Authors's photo

определенная часть костей животных подвергнута воздействию окисления.

Культурный горизонт периода ранних кочевников не интенсивный, наполненный редкими культурными остатками, такими как фрагменты керамики, трехлопастной втульчатый наконечник стрелы, остеологический материал.

Помимо поселения Балкан в крайней западной части террасы, в месте перехода равнины в небольшую возвышенность были обнаружены каменные конструкции, вероятно, захоронения этнографического времени. Схожие конструкции обнаружены также на противоположной стороне реки. Кроме того, среди подъемного материала можно назвать редкие находки станковой керамики периода Средневековья.
Наличие артефактов, относящихся к бронзовому веку, культурные остатки раннего железного века, а также редкие находки фрагментов керамики периода Средневековья позволяют судить о долговременном заселении человеком урочища Балкан, от эпохи бронзы вплоть до средневековья и этнографического времени.

В целом, археологический материал урочища Балкан достаточно актуален в свете изучения и корреляции известных сведений о ЖезказганУлытауском ГМЦ.

\section{Bblводbl}

Полевые исследования 2020 г., в том числе рекогносцировочные работы и составление карты локализации археологических объектов эпохи бронзы Жезказган-Улытауского региона с нанесением координат извест- 
ных местонахождений памятников и дополнение полученных картографических материалов информацией о новых объектах археологии, позволили определить основную локализацию древних памятников в регионе, а также произвести корреляцию известных сведений о распространении геоархеологических производственных объектов и археологических памятников различных категорий по региону.
Подводя предварительные итоги проведенной работы, отметим, что изучение геоархеологических производственных объектов и археологических памятников необходимо продолжить в русле комплексных изысканий с применением естественнонаучной методологии. Особенно перспективными для дальнейших изысканий могут выступить слабо изученные районы западной и северо-западной части Жезказган-Улытауского региона.

\section{ЛИТЕРАТУРА}

1. Валукинский Н.В. Поиски и разведки. 1949а // Архив Института археологии им. А.Х. Маргулана. Ф. 2, д. 143, 138 л.

2. Валукинский Н.В. Отчет о раскопках в урочище Милы-Кудук заводского двора. 1949б // Архив Института археологии им. А.Х. Маргулана. Ф. 11, д. 173, 18 л.

3. Валукинский Н.B. Раскопки в урочище Милекудук в Южной части рудника Джезказгана // Известия АН КазССР. Сер. археол. 1949в. Вып. 2. С. 122-125.

4. Маргулан А.Х. К изучению памятников района р. Сары-Су и Улутау // Вестник АН КазССР. 1948. № 2 (35). С. 53-60.

5. Маргулан А.Х. Открытие новых памятников культуры эпохи бронзы Центрального Казахстана // XXV Международный конгресс востоковедов. Доклады делегаций СССР. М.: изд-во Вост. лит., 1960. 12 с.

6. Маргулан А.Х. Сочинения: В 14 т. Т. 2. Сарыарка. Горное дело и металлургия в эпоху бронзы. Джезказган - древний и средневековый металлургический центр (городище Милыкудук) / Сост. Д.А. Маргулан, Д. Маргулан. Алматы: Дайк-Пресс, 2001. 144 с. + вкл. 40 c.

7. Маргулан А.Х., Агеева Е.И. Археологические работы и находки на территории Казахской ССР // Известия АН КазССР. Сер. археол. 1948. Вып. 1. С. 129-135.

8. Маргулан А.Х., Акишев К.А., Кадырбаев М.К., Оразбаев А.М. Древняя культура Центрального Казахстана. Алма-Ата: изд-во «Наука» КазССР, 1966. 436 с.

9. Сатпаев К.И. Доисторические памятники в Джезказганском районе // Народное хозяйство Казахстана. 1941. № 1. С. 69-70.

10. Сатпаев К.И. Основные специфические особенности геологии и металлогении Джезказган-Улытауского района // Материалы к металлогенической прогнозной карте Центрального Казахстана. Алма-Ата: изд-во АН КазССР, 1956. Листы: М-42-В, L-42-A.

\section{REFERENCES}

1. Valukinskiy, N. V. 1949a. In: Archive of A.Kh. Margulan Institute of Archeology. Fund 2, case no. 143, 138 sheets (in Russian).

2. Valukinskiy, N. V. 1949б. In: Archive of A.Kh. Margulan Institute of Archeology. Fund 1, case no. 173, 18 sheets (in Russian).

3. Valukinskiy, N. V. 1949B. In: Izvestiya AN KazSSR. Seriya arheologicheskaya (News Academy of Sciences KazSSR, Archaeological series), 2, 122-125 (in Russian). 
4. Margulan, A. Kh. 1948. In: Vestnik AN KazSSR (Bulletin of the Academy of Sciences of the Kazakh SSR), 2 (35), 53-60 (in Russian).

5. Margulan, A. Kh. 1960. In: 25 Mezhdunarodnyj kongress vostokovedov. Doklady delegacij SSSR (25 $5^{\text {th }}$ International Congress of Orientalists. Reports of the delegations of the USSR). Moscow: "Vostochnaya literatura" Publ. (in Russian).

6. Margulan, A. Kh. 2001. Sochineniya: V 14 t. T. 2. Saryarka. Gornoye delo i metallurgiya v epokhu bronzy. Dzhezkazgan - drevniy i srednevekovyy metallurgicheskiy tsentr (gorodishche Milykuduk) (Works: In 14 volumes. T. 2. Saryarka. Mining and Metallurgy in the Bronze Age. Dzhezkazgan - an ancient and medieval metallurgical center (settlement of Milykuduk) / Comp. D. A. Margulan, D. Margulan. Almaty: "Daik-Press" Publ. (in Russian).

7. Margulan, A. Kh., Ageyeva, E. I. 1948. In Izvestiya AN KazSSR. Seriya arheologicheskaya (News Academy of Sciences KazSSR. Archaeological series), 1, 129-135 (in Russian).

8. Margulan, A. Kh., Akishev, K. A., Kadyrbayev, M. K., Orazbayev, A. M. 1966. Drevnyaya kultura Tsentralnogo Kazakhstana (Ancient culture of Central Kazakhstan). Alma-Ata: "Nauka" Publ. of the Kazakh SSR (in Russian).

9. Satpaev, K. I. 1941. In: Narodnoe hozyajstvo Kazahstana (National economy of Kazakhstan), 1, 69-70 (in Russian).

10. Satpaev, K. I. 1956. In Materialy k metallogenicheskoy prognoznoy karte Centralnogo Kazahstana (Materials for the metallogenic forecast map of Central Kazakhstan). Alma-Ata: Academy of Sciences of the Kazakh SSR. Sheets: M-42-B, L-42-A (in Russian).

\footnotetext{
Мүдделер қақтығысы туралы ақпаратты ашу. Авторлар мүдделер қақтығысының жоқтығын мәлімдейді. / Раскрытие информации о конфликте интересов. Авторы заявляют об отсутствии конфликта интересов.

/ Disclosure of conflict of interest information. The authors claims no conflict of interest.

Мақала туралы ақпарат / Информация о статье / Information about the article.

Редакцияға түсті / Поступила в редакцию / Entered the editorial office: 20.08.2020.

Рецензенттер мақұлдаған / Одобрено рецензентами / Approved by reviewers: 23.08.2020.

Жариялауға қабылданды / Принята к публикации / Accepted for publication: 29.08.2020.
} 